\title{
SNOW GOOSE SUCCESSFULLY COUNTERATTACKS BALD EAGLE
}

W.J. WALLEY, 222 Bossons Avenue, Dauphin, MB R7N OR2

Although the Bald Eagle is well known as a predator of fish and as a scavenger, its habit of attacking waterfowl, inluding geese, is also well documented. This report cites a goose - eagle interaction with a different twist.

At mid-morning 17 October, 1992 in ompany with Claudette Fern Clyde, a one blue phase Snow Goose was spoted as it stood on a worked field some $00 \mathrm{~m}$ east of our vantage point in my ehicle. The bird was situated about 80 n south of the dike road along Edward's Freek approximately $1.5 \mathrm{~km}$ west of the reek estuary in the southwest corner f Lake Dauphin. The goose was asumed to be injured, possibly wounded y a hunter's shot, and left behind by pe flock. Overcast, calm and mild conitions prevailed.

While observing with $7 x$ binoculars, n immature Bald Eagle appeared furer east at a considerable altitude and egan a long gradual descent in the diection of the goose which, it became pparent, had been targeted. The pptor's speed, though steady, was not pectacular as it approached its quarry. econds before making contact with the oose, the eagle checked its descent hanging its attitude of attack from an ngular one to a hovering-vertical-drop rectly toward the goose. Suddenly, the oose burst upward and engaged the agle 5-6 $\mathrm{m}$ above the earth with its back prtical to the ground and its clawed feet rust outward to meet the predator's utstretched legs and talons. The aerial kirmish, which involved frantically beat$g$ wings of both birds, was over in less than 3 seconds with the goose returning to the ground fully in control of its flight. The eagle flew upward with typical laboured wing-beats an estimated $150 \mathrm{~m}$ then flew off to the southwest before turning back toward the lake in a long arc. There was no indication that the attack would be repeated.

We then drove along the dike-road until opposite the goose where I proceeded toward it on foot. When within $50 \mathrm{~m}$ of it, the goose took wing flying powerfully to the southeast at a low angle a distance of $250 \mathrm{~m}$ and disappeared over aspen woods.

It is not certain that the goose actually flew straight up to meet its attacker. There is some question that a goose is even capable of this. However, from our vantage point it certainly appeared to. On the other hand, had it been viewed from the south or north rather than from the west, we may have seen it rise at an angle or nearly so. Why did the eagle fail to take the goose? As an immature, it was possibly surprised by the counterattack. Its tentative approach to its intended prey - its slow gradual descent; hovering and settling-on-its-prey approach instead of a swooping-grasping attack, suggested inexperience on the part of the eagle, likely a juvenile as indicated by its very dark plumage. Did the aggressive behaviour on the part of the goose stem from its ability to sense the inexperience of the eagle and was it able to further sense that attacking the eagle was a better survival tactic than resorting to escape flight? Perhaps it didn't even see the eagle until the last 
few seconds of the attack which may have been a factor in how it arose to meet its adversary.

1. BENNETT, R.S.JR. AND E.E. KLAAS. 1986. The Bald Eagle pursues and injures Snow Goose in flight. Raptor Research 20(2): 75-76.

2. BENT, A.C.1961. Life histories of North American birds of prey. Part One. Dover Publishing Co.

3. COOKE, F, R.K.ROSS, R.K.SCHMIDT, AND PAKULAK, A.J. 1975. Birds of the tundra biome at Cape Churchill and LaPeruse Bay. Canadian Field-Naturalist 89 (4): 413 - 422.

4. DEKKER, D. 1984 Migrations and foraging habits of Bald Eagles in eastcentral Alberta, 1964 - 1983. Blue Jay 42 (4): 199-205.
5. GERRARD, J.M. AND G.R.BORTOLOTTI. 1988. The Bald Eagle: haunts and habits of a wilderness monarch. A Smithsonian Nature Book Western Producer Prairie Books Saskatoon, Saskatchewan. 177pp.

6. KNOGHT, R.L., P.J. RANDOLPH G.T.ALLEN L.S.YOUNG, AND W.J WIGHEN. 1990. Diets of nesting Balc Eagles, Haliaeetus leucocephalus, in western Washington. Canadian Field. Naturalist 104 (4): 545-551.

7. MCILHERRY, E.A. 1932. The Blue Goose in its winter home. Auk 49: 279 306. (In J.M. Gerrard and G.T. Bortolott 1988)

8.NERO, R.W. 1987, Additional record of Bald Eagle predation of waterfow Blue Jay 45 (1): 28-29

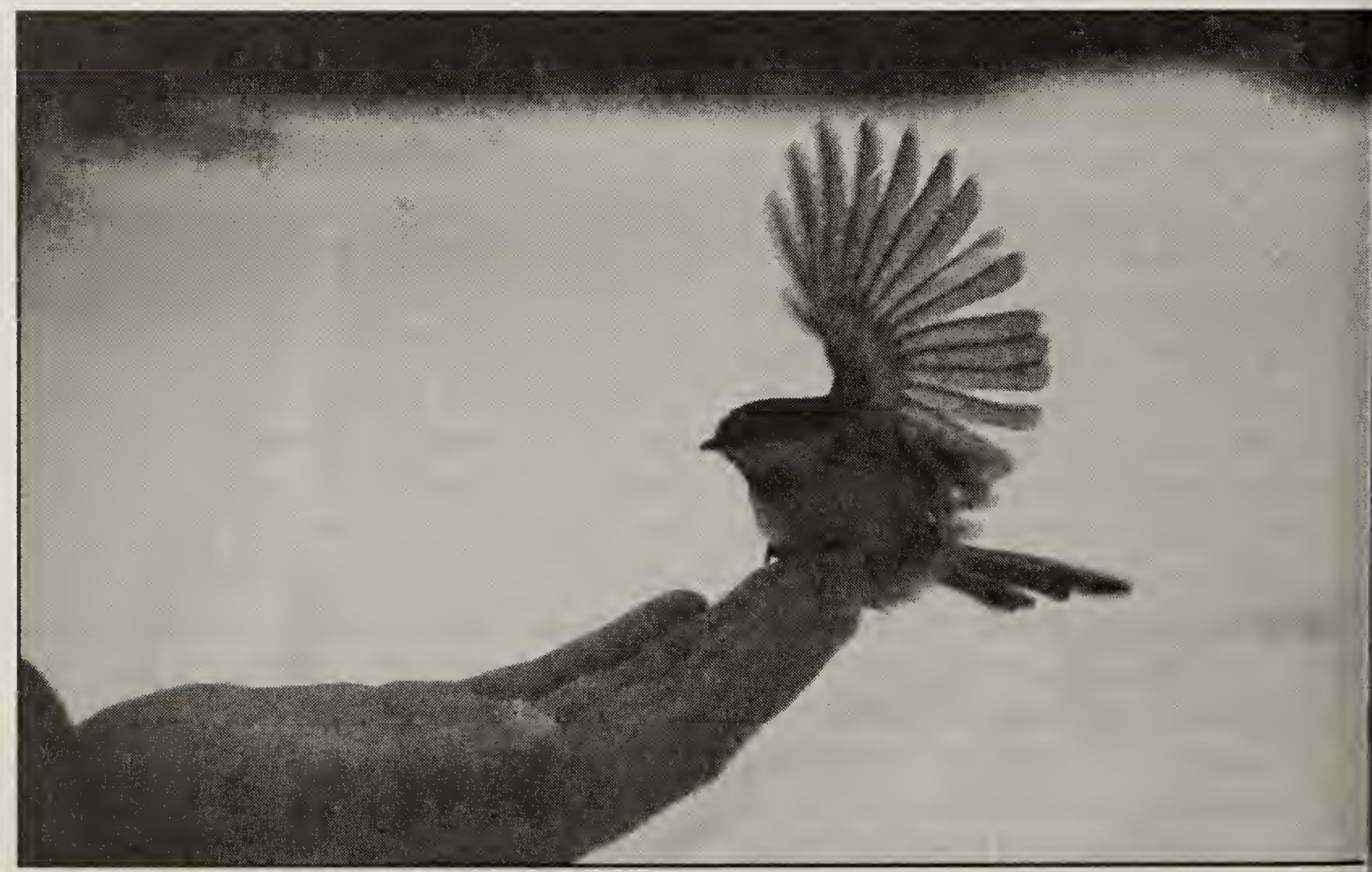

